\author{
Research Article \\ www.ijrap.net (ISSN:2229-3566)
}

\title{
EFFECT OF SHARAPUNKHA (TEPHROSIA PURPUREA) ON GASTROINTESTINAL SYSTEM
}

Manojkumar $^{1 *}$, Sangeeta Gehlot ${ }^{2}$

${ }^{1}$ Lecturer, Department of Kriya Sharir, Lalit Hari P.G. State Ayurvedic College and Hospital, Pilibhit,

Uttar Pradesh, India

${ }^{2}$ Professor and Head, Department of Kriya Sharir, Faculty of Ayurveda, Institute of Medical Sciences, Banaras Hindu University, Varanasi, India

Received on: 09/07/20 Accepted on: 18/08/20

\author{
*Corresponding author \\ E-mail: mkmanojdr848@gmail.com
}

DOI: 10.7897/2277-4343.1105142

\begin{abstract}
Sharapunkha (Tephrosia purpurea) is one of the important drugs in Ayurvedic system of medicine. The present study was undertaken to find out the action of Sharapunkha (Tephrosia purpurea) on Gastrointestinal System. During the passage of drug through oral route, it is probable that the active principle present in Sharapunkha, might act on gastrointestinal System. Albino rats were used in this study and divided into control and drug treated group. Drug treated group rats were feed with intragastric drug decoction, along with their normal water and food. Water intake, diet intake, weight of rats, gastrointestinal motility and serum bilirubin level were compared. Healthy human volunteers were selected, and prepared drug decoction was given for 7 days. Observations were done based on self-assessment of the volunteers about any significant physiological variation specially related to the G.I. System. After study, it was found that Sharapunkha enhances intestinal motility, decreases serum bilirubin in albino rats. Human volunteers had feeling of increase appetite, easy bowel motion and increase urge for micturition. These facts suggest that some ingredients of Sharapunkha are acting on the smooth muscles of the bowel and urinary bladder. So, it may be presumed that Sharapunkha influences the feeding and satiety center located in hypothalamus. Sharapunkha decoction preparation does influence the activity of the autonomic nervous system with consequent alterations in the functions of gastrointestinal tract and possibly the urinary system.
\end{abstract}

Keywords: Annavaha Srotas, Koshtha, Mahasrotas, Sharapunkha, Tephrosia purpurea.

\section{INTRODUCTION}

The main aim of Ayurveda is to provide guidelines for maintenance and promotion of health as well as prevention and then treatment of diseases. The Science of Ayurveda primarily involves the use of the products of plant origin. Since before Vedic period, man had close contact with the nature especially with plants. Sharapunkha (Tephrosia purpurea) is one of the important drugs in Ayurvedic system of medicine. We find description about the use of Sharapunkha (Tephrosia purpurea) root in Sushruta Samhita and Ashtanga Hridaya for various disease $^{1,2}$. In almost all Nighantus, main use of Sharapunkha (Tephrosia purpurea) is described related to liver and splenic diseases. Various recent studies reflect that it has some effect on different systems like Gastrointestinal System, Cardiovascular System, Respiratory System and others. Keeping all the references in mind an experimental study on Albino rats along with a general study on healthy human volunteers were done to explore whether Sharapunkha (Tephrosia purpurea) has some effect on Gastrointestinal System.
Sharapunkha (Tephrosia purpurea) is a self-generating, erect or spreading perennial herb found throughout India. It can be found as an ingredient in traditional herbal formulations. Tephrosia purpurea belongs to Fabaceae family and Leguminosae (Papilonaceae) Sub-family, commonly known in as 'Sarapunkha' in sanskrit ${ }^{3}$. Two varieties are described in Ayurvedic texts as rakta and Shweta. Whole plant and various parts of the plant are useful as Ayurvedic medicines. Traditionally drug is used as liver tonic. Three new unusual flavonoids tephroglabrin, tepurindiol and O-methylpongamol have been isolated from roots along with seven known closely related flavonoids and structure of a new compounds determined ${ }^{4}$ (Figure 1); $\beta$-sitosterol, lupeol and rutin from leaves of the plant. Purpuritencin A and B and Purpureamethide were isolated from seeds Isolanchocarpin, Pongamol, Lanceolatin A, Lanceolatin B, Karanjin, Kanjone and $\beta$-Sitosterol, isolated from roots and seeds ${ }^{5}$. Root is also recommended for boils, pimples abscesses, especially carbuncle on the back, as tonic and laxative ${ }^{6}$. The powder of the root consumed with buttermilk for one month completely cures swelling, anemia, pimple and eruption, it is diuretic, allays thirst, enrich blood, cures diarrhea, useful in bronchitis, asthma, liver and spleen diseases, inflammations, boils and pimples ${ }^{7}$. 


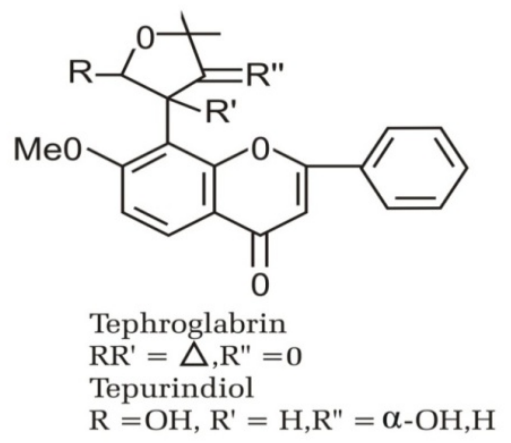<smiles>COC(=CC(=O)c1ccc2occc2c1OC)c1ccccc1</smiles>

Q-Methylpongamol

Figure 1: Flavonoids found in the Root of Sharapunkha (Tephrosia purpurea)

\section{Concept of gastrointestinal tract in Ayurveda}

The gastrointestinal tract is described by various terms like Mahasrotas, Annavaha Srotas and Koshtha etc. Charaka has described stomach and small intestine in Annavaha Srotas ${ }^{8}$. The description of Grahani is mentioned by Charaka, Sushruta, Vagbhata and other scholars also; grahani the seat of Agni which is the curved upper part of the small intestine and joined with the pyloric end of stomach, so it can be correlated with duodenum ${ }^{9}$. It is the place where bile and pancreatic juice reach and they act upon to split food. The Pakwashaya (large intestine) is associated with the digested food and performs the function of absorption and distribution. So the Mahasrotas and Koshtha are treated as gastro-intestinal tract as a whole ${ }^{10}$.

\section{MATERIAL AND METHODS}

\section{Drug preparation}

Sharapunkha was collected from the grass field of BHU campus in the months of August-October 2004. Drug was authenticated by Dravya- Guna Department, BHU. Roots were separated from the rest of the plants and washed thoroughly and dried in shade for 7-10 days. After drying, fine grinding of root was done. For the preparation of decoction of drug, 6 gram of root powder was taken, and $100 \mathrm{ml}$ of water was added to it in a beaker. The contents were heated on a slow flame. The procedure of heating and boiling the mixture was continued till solvent was reduced to $1 / 4^{\text {th }}$ of its original volume. The mixture was filtered through a sieve with pore size No.1/120. The total time taken in boiling the mixture was around $30-40$ minutes $^{11}$.

\section{Study on Albino rat}

Total 12 albino rats were selected for gastrointestinal tract study and divided into two groups. Group I (control) and Group II (drug treated). Each group comprised of 6 albino healthy rats of Charles Foster strain (weighing $160 \mathrm{gm}-200 \mathrm{gm}$ ). The rats were kept under standard laboratory conditions (Temperature $27 \pm 2^{\circ} \mathrm{C}$ related humidity of $65 \%, 12$ hours light and dark cycle). They were fed with standard rat food and water ad libitum. Animals were ethically treated throughout study. Root powder decoction of Sharapunkha was fed by intra gastric route in known doses $(0.5$ $\mathrm{mg} / \mathrm{gm}$. body weight) every morning for 21 days.

\section{Measurement of Food intake, Water Intake and Weight of Rats}

In group II (drug treated), Sharapunkha root powder decoction was fed by intra gastric route in proper doses, every morning for
21 days. Food intake, water intake and weight of rats in control as well as in drug treated group were measured. The control group animals were given water only (equal volume of tap water). During this period, both group rats were given rat-diet and water ad libitum. The diet, water consumption and the change in weight of rats were recorded.

\section{Study for gut motility}

For the assessment of gut motility of rat, microbar powder suspension administered (a palatable micronized BaSO4 92\% w/v from ESKAY fine chemicals). The rats were fasted for 12-14 hours. After 30 minutes of the administration of microbar suspension, the rats of both groups were sacrificed by Pithing and measured the $\mathrm{BaSO}_{4}$ powder travelled distance in $1 / 2$ hour. The intestine was measured from starting of first part of duodenum to the ileocaecal junction ${ }^{12}$.

\section{Study on healthy human volunteers}

Total 30 volunteers were registered for this study 20 being males and 10 females. Consent of the young male and female volunteers aged 25-35 years was taken before starting the study. Study was carried out by following ethical standards. The volunteers were healthy male and female students and workers of the Institute of Medical Sciences, BHU. It was ensured that the volunteers did not suffer from any acute or chronic disease. It was also seen that the volunteers were not addicted to any drug. Some of the volunteers were vegetarian and others were occasionally nonvegetarians. For human volunteers $0.5 \mathrm{ml} / \mathrm{kg}$ of the prepared decoction $(100 \mathrm{mg} / \mathrm{kg}$ body weight) was given twice daily for 7 days after meal.

In healthy human volunteers, it was observed whether they feel any changes in their hunger, thirst, micturition, bowl motion or any other physiological changes, by putting up questions related to G.I. System.

\section{RESULT}

\section{Albino Rat}

\section{Water intake}

Water intake was found increased in group II in comparison to group I (control). Water intake varied from $32.08 \pm 6.92$ to 37.23 \pm 5.20 in group II while in group I (control group) it was found $26.33 \pm 4.86$ to $35.58 \pm 7.05$ as shown in Table 1 . 
Table 1: Effect of Sharapunkha on water intake, food intake and weight of Albino Rats

\begin{tabular}{|c|c|c|c|c|}
\hline \multirow{2}{*}{ Parameter } & Mean \pm S.D. & Day 1 to Day 21 & \multicolumn{2}{c|}{ Inter-Group Comparison } \\
\cline { 2 - 5 } & Group I (Control) & Group II (Drug Treated) & t-value & p-value \\
\hline Water Intake (ml/day) & $28.23 \pm 2.11$ & $33.36 \pm 1.43$ & $\mathrm{t}=9.23$ & $\mathrm{p}<0.001 H S$ \\
\hline Food Intake (gm/day) & $17.81 \pm 1.34$ & $21.10 \pm 1.50$ & $\mathrm{t}=18.93$ & $\mathrm{p}<0.001 H S$ \\
\hline Weight (gm/day) & $183.02 \pm 5.53$ & $182.34 \pm 5.58$ & $\mathrm{t}=0.83$ & $\mathrm{p}>0.05 \mathrm{NS}$ \\
\hline
\end{tabular}

P value (Water Intake): $\mathrm{p}<0.001$, Highly Significant. P value (Food Intake): $\mathrm{p}<0.001$, Highly Significant. $P$ value (Weight of Rat): $p>0.05$, Not Significant.

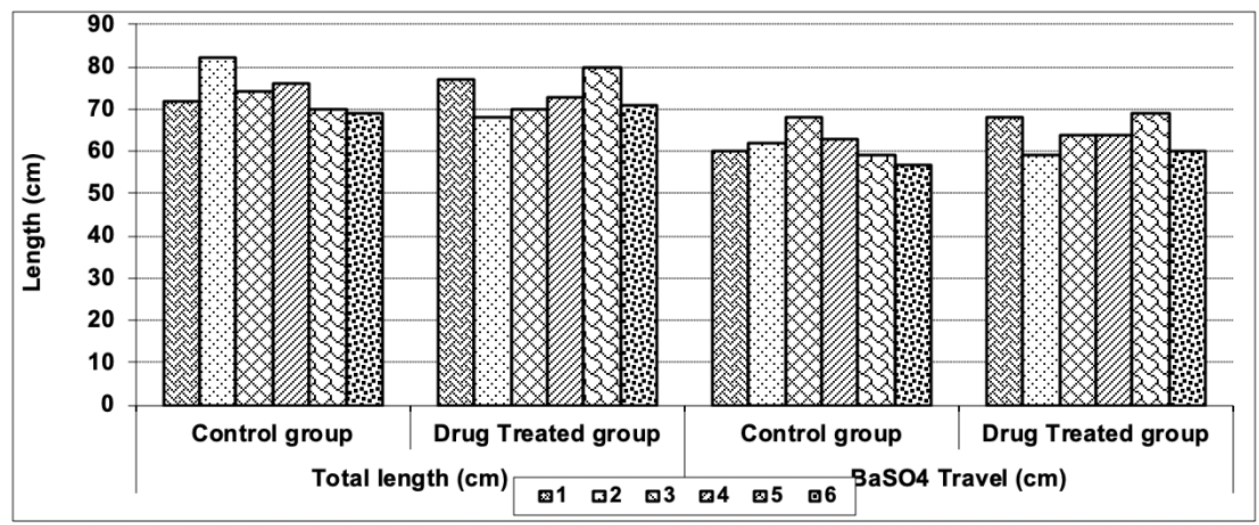

Figure 2: Effect of Sharapunkha root powder decoction on intestinal motility (duodenum to ileocaecal junction) in Albino Rats by using microbar solution

$P$ value (Control group): $p>0.05$ Not Significant. $P$ value (Drug Treated group): $p>0.05$ Not Significant

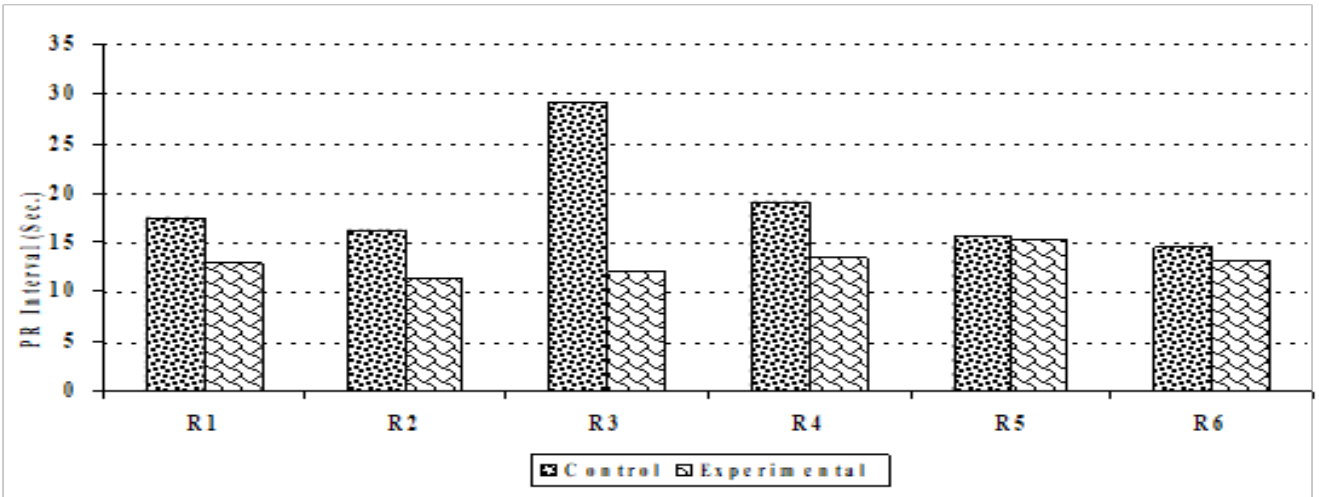

Figure 3: Values of S. Bilirubin level in Control and Drug Treated group of Albino Rats after intragastric administration of Sharapunkha root powder decoction

$\mathrm{P}$ value (Drug Treated group): $\mathrm{p}<0.05$, Significant

\section{Food intake}

Food intake (gm/day) slightly increased during 21 days in drug treated group. Statistically significant change was observed. (Table 1).

\section{Weight}

Weight of rats was not significantly altered in control as compared to drug treated groups as shown in Table 1.

\section{Intestinal Motility}

Mean \pm S.D. of intestinal length in group I and group II was found $73.83 \pm 4.75$ and $73.17 \pm 4.54$, respectively. To assess the intestinal motility, the distance traveled by BaSO4 solution was found more in drug treated group (Group II) in comparison to control group (Group I) as shown in Figure 2.

\section{Serum Bilirubin (mg\%)}

Mean serum bilirubin level was found $18.68 \pm 5.34$ and $13.00 \pm$ 1.31 in group I and group II respectively. Decrease in serum bilirubin was observed in group II as compared to group I. Statistical analysis of group I vs group II revealed significant decrease in serum bilirubin as shown in Figure 3.

\section{Human Volunteers}

On enquiring the general health of the volunteers, it was revealed that the volunteer's taking Sharapunkha (Tephrosia purpurea) doses for 7 days had a feeling of increased appetite, easy bowel motion and increased frequency of micturition.

\section{DISCUSSION}

Drug influences and enhances the gastrointestinal tract motility in the Albino rat as seen by the observation from Figure 2. These observations tend to strengthen the view that constituents of 
Sharapunkha have a stimulant effect on smooth muscles of the gut. It is well known that sympathetic stimulation reduces gut motility while the parasympathetic stimulation enhances the gut motility ${ }^{13}$. Ramamurthy and Srinivasan studied the hepatoprotective effect of Tephrosia purpurea and also reported decrease in serum bilirubin level ${ }^{14,15}$. The observations made in the present study suggest an alteration in the bilirubin level in plasma of rats. No definite reason can be attributed to this change in bilirubin contents in the rats.

The observations of the present study suggest that Sharapunkha enhances appetite, raise the sense of well-being, facilitates the bowel movements and increases the frequency of micturition in human volunteers. The present study does not provide any clue and cannot differentiate the effect of the drug on sympathetic and parasympathetic components of the autonomic nervous system; however the present observations clearly suggest that Sharapunkha decoction preparation does influence the activity of the autonomic nervous system with consequent alterations in the functions of gastro intestinal tract and possibly the urinary system $^{16}$. These facts suggest that some active principles from Sharapunkha had been acting on the smooth muscles of the bowel and also the smooth muscles of urinary bladder and probably, these active principles in Sharapunkha might have gain access to the central nervous system to cross the blood brain barrier and influence the feeding and satiety center located in hypothalamus. This is the first kind of the observation which suggests that the use of Sharapunkha as tonic has a scientific footing.

\section{CONCLUSION}

The effect of Sharapunkha decoction on bowel habits as well as urinary bladder is the first proof which brings into light the action of the drug on smooth muscles of gut and the urinary bladder; however the active principle that is present in Sharapunkha (Tephrosia purpurea) acting on the smooth muscles remains to be isolated. So, further longitudinal and more extensive studies are needed with large sample size to explore exact mechanism of action of the drug.

\section{REFERENCES}

1. Kaviraja Shastri Ambikadutt, edited with Ayurveda Tattva Sandipika, Sushruta Samhita, Part I, Kalpa sthana (7/53): Chaukhambha Sanskrit Sansthan, Varanasi; 1997. p. 62.

2. Vaidya Lalchandra with Sarwanga Sundari commentary by Arunadatta, Vagbhata Ashtanga Hridaya, Uttar Tantra (30/26): Motilal Banarasidas Publishers, Delhi; p. 748.

3. Kumar Manoj, Gehlot Sangeeta. Effect of Tephrosia purpurea (Sarapunkha) on Cardiovascular System: International Journal of Ayurvedic and Herbal Medicine 2020; 10(4): 3787-3794. http://interscience.org.uk/index.php/ ijahm.
4. Rastogi Ram and Mehrotra B.N. Compendium of Indian Medicinal Plants. Volume 3, CDRI, Lucknow; 1980-1984. p. 631-633.

5. Pankti P Dalwadi. Tephrosia purpurea Linn (Sharpunkha, Wild Indigo): A Review on Phytochemistry and Pharmacological Studies, Indian Journal of Pharmaceutical and Biological Research (IJPBR).

6. Ghosh Jaya Nanda, Ethno botanical study of Western Maharashtra, Department of Botany, SDM's College, Palghar, Ethno botany in South Asia; 1996.

7. Mitra S.K., Venkataranganna M.V., Sundaram R., Gopumadhavan S. The Himalaya Drug Company, 1999, MAPA, CSIR 1999; 21(4): 480.

8. Shastri Kashinath, Chaturvedi Gorakhnath (Reprinted edition) Charaka Samhita of Agnivesh, Vol-I Vimana Sthana (5/6-7), Chaukhambha Bharati Academy, Varanasi; 1998. p. 711.

9. Kaviraja Shastri Ambikadutt, edited with Ayurveda Tattva Sandipika, Sushruta Samhita, Sutra sthana (5/40); Part I: Chaukhambha Sanskrit Sansthan, Varanasi; 1997. p. 19.

10. Vagbhata. Ashtanga Samgraha, English translation by Srikanta Murty KR, Vol-I, Sutra-Sthana (1/26), Chaukhambha Orientalia, Varanasi; 2001.

11. Vagbhata. Ashtanga Samgraha, English translation by Srikanta Murty KR, Vol-I, Sutra-Sthana (1/26), Chaukhambha Orientalia, Varanasi; 2001. p. 8.

12. Kumar Manoj, Gehlot Sangeeta. Effect of Tephrosia purpurea (Sarapunkha) on Cardiovascular System: International Journal of Ayurvedic and Herbal Medicine 2012; 2(2): 328-335. Journal Homepage http://interscience. org.uk/index.php/ijahm.

13. Prajapati Mahendra P. Effect of Albizia lebbeck on Hunger and Gastrointestinal Tract Function; 2004. IMS, BHU, Varanasi.

14. Guyton C., Hall John E. Textbook of Medical Physiology, $10^{\text {th }}$ edition, Published by Elsevier: General Principles of Gastrointestinal Function-Motility, Nervous Control and Blood Circulation; 2003. p. 718-724.

15. Ramamurthy M.R. and Srinivasan M. Indian Journal of Pharmacology 1993; 25: 34-36.

16. Afzal S.G., Mohan M.P.J., Swamy P.N., Kumar K.R. A study of Tefroli in viral hepatitis and evaluation of clinical, biochemical and serological improvement. MAPA, CSIR 1983; 5(2): 109.

17. Kumar Manoj, Gehlot Sangeeta. Systemic effect of Sarapunkha on Cardiovascular System: An Experimental Study, JETIR July 2020; 7(7): 163-167. www.jetir.org

\section{Cite this article as:}

Manojkumar and Sangeeta Gehlot. Effect of Sharapunkha (Tephrosia Purpurea) on Gastrointestinal System. Int. J. Res. Ayurveda Pharm. 2020; 11(5):60-63 http://dx.doi.org/10.7897/ 2277-4343.1105142 